\title{
Koncepcionális átalakulásra szorul a hazai intenzív ellátás
}

Érdeklődéssel olvastuk dr. Gresz Miklós ebben a lapszámban megjelenő összefoglalóját a magyarországi intenzív osztályok helyzetével kapcsolatban. A közlemény az OEP adatbázisai alapján foglalja össze az intenzív ellátás helyzetét, és megállapítja, hogy a hazai intenzív osztályok ágykihasználtsága alacsony, ezért nem tûnik indokoltnak az ágyszám növelése, sőt, inkább az ágyszámok csökkentése merül fel.

A magunk részéról a közlemény megállapításainak legtöbbjével, néhány megszorítással, egyetértünk. Nevezetesen a helyzet a valóságban még annál is rosszabb, mint amennyire az a közleményből kiolvasható. Az Aneszteziológiai és Intenzív Terápiás Szakmai Kollégium 2006-ban elkészítette a szakma fejlesztésének 10 éves koncepcióját. Ennek részeként egy, a korábbitól jelentősen eltérő koncepcionális alapokon nyugvó minimumfeltétel-rendszert javasoltunk. Míg korábban évtizedeken keresztül a minimumfeltételeket az határozta meg, hogy az illető intenzív osztály milyen földrajzi elhelyezkedésű (azaz városi, megyei vagy egyetemi ellátóhelyen van), addig ez az új minimumfeltétel-elképzelés a betegek állapotsúlyosságát veszi figyelembe és ahhoz rendeli hozzá a tárgyi és személyi minimumfeltételeket. Az intenzív osztályon előforduló betegösszetételnek megfelelően ily módon valamennyi intenzív osztály besorolható a szakági szubintenzív, illetve I-II-III. fokozatú intenzív osztályok valamelyikébe. A kollégium javaslata szerint a finanszírozást is ehhez, a betegségsúlyosság alapján kialakított rendszerhez kellene illeszteni. Köztudott ugyanis, hogy a valóban intenzív terápiát igénylő, többszervi elégtelenségben szenvedő betegek finanszírozása jelenleg körülbelül a költségek egyharmadát fedezi. Magunk osztjuk a szerző véleményét, amely szerint nem az intenzívágy-szám növelésére, hanem azok átstrukturálására és ezt követően a megfelelő finanszírozás hozzárendelésére van szükség.

\section{Milyen lebetôségek mutatkoznak erre?}

- Létre kell hozni egy szigorú, az európai normáknak megfelelő intenzív osztályos feltételrendszert, amely leírja, hogy milyen személyi és műszeres feltételek

$$
\begin{aligned}
& \text { Prof. dr. Gál János } \\
& \text { SOTE AITK } \\
& \text { MAITT elnöke }
\end{aligned}
$$

szükségesek egy-egy adott szintű intenzív osztály akkreditációjához.

- A fenti szempontrendszernek történő megfelelést ellenórizni kell, és az akkreditációt csak ennek megfelelően kapják az intenzív osztályok.

- Az intenzív osztályos esetek finanszírozását újra kell gondolni és a progresszivitásnak megfelelő mértékben pluszforrást kell biztosítani az intenzív ellátásra szoruló betegek kezelésére.

- Szigorúbb szabályozókkal vissza kell szorítani azt, hogy „kreatív kódolással” „súlyos kíséró betegségek”, illetve „emelt szintű monitorozás igénye” miatt növekedjen meg az intenzív osztályok forgalma.

- Az intenzív osztályos dologi költségek jobb monitorozhatósága érdekében megfontolandónak tartjuk egy vonalkódalapú tételes költségkövetés bevezetését, amellyel a betegbe beadott gyógyszerek mennyisége, az alkalmazott invazív eszközök száma, a kért laboratóriumi vizsgálatok száma jól követhető. Ilyen módon kiszűrhetők lennének a csak megfigyelt vagy valójában intenzív ellátást nem igénylő esetek.

- További gond az is, hogy az intenzív osztályos ágyak egy jelentős részét olyan betegek foglalják el, akik tartós lélegeztetést igényelnek, de egyéb intenzív terápiás beavatkozást már nem (kóma, tartós vegetatív állapot, progresszív ideg-izom betegségek stb.). Halaszthatatlannak túnik a valódi intenzív ágyak kiváltása olyan tartós lélegeztetésre képes intermediaer care osztályokkal, ahol ezeket a feladatokat is végre lehet hajtani.

Összefoglalva: Azt gondoljuk, a szerzőnek sok tekintetben igaza van. Az intenzív ágyszám alacsony kihasználtsága részben strukturális anomáliákra, részben finanszírozási okokra vezethető vissza. Egy szigorú akkreditációs feltételrendszer kidolgozásával, a valós értékén finanszírozott intenzív betegellátással és a sürgősségiintenzív-intermediaer ellátás átszervezésével hatékonyabban lehetne a forrásokat kihasználni. Ráadásul - és ez a legfontosabb szempont - a betegeink szakmai szempontból is sokkal jobban járnának.

\section{Prof. dr. Fülesdi Béla \\ DEOEC AITT}

A Szakmai Kollégium elnöke, a Szakmai Kollégium Aneszteziológiai és Intenzív Terápiás Tagozatának elnöke 